\title{
Experimental plot size of passion fruit
}

\author{
Glaucia Amorim Faria ${ }^{1}$, Beatriz Garcia Lopes ${ }^{2}$, Ana Patrícia Bastos Peixoto ${ }^{3}$, \\ Antonio Flávio Arruda Ferreira ${ }^{4}$, Kátia Luciene Maltoni ${ }^{5}$, Lucas Bernardo Pigari ${ }^{6}$
}

\begin{abstract}
The determination of the plot size is a practical matter pertinent to the experimental planning, and its optimal characterization allows to obtain higher precision and better quality in the results. Therefore, in this study, the main goal was to determine the plot size in experiments of passion fruit in two uniformity tests with Passiflora setacea and Passiflora alata. The experiment was constituted of a substrate at planting with 3 thirds of soil and 1 of barnyard manure. The soil was fertilizer with $3 \mathrm{~kg}$ of simple superphosphate and $0.5 \mathrm{~kg}$ of $\mathrm{KCl}$ by $1 \mathrm{~m}^{3}$. Each species of Passiflora was considered a uniformity test with 40 basic units (BU). The evaluations of the experiments were done on 60 days after the transplant, noticing the tree's height, stem's diameter, number of leaves, number of buds, number of meristems and chlorophyll. Several plot sizes were simulated, in which each plant was first considered as a basic unit up to 40 plants per unit basic. For the estimation of optimum plot size, the maximum modified curvature method was used. The plot sizes varied with the specie, founding values as three to seven BU for Passiflora setacea and four BU to five for Passiflora alata.
\end{abstract}

Index terms: Experiental Planning, Experimental Precision, Passiflora setacea, Passiflora alata.

\section{Tamanho de parcela experimental em maracujá}

Corresponding author: glaucia.a.faria@unesp.br

Received: August 15, 2019 Accepted: October 31, 2019

Copyright: All the contents of this journal, except where otherwise noted, is licensed under a Creative Commons Attribution License.
Resumo - A determinação do tamanho de parcela é uma questão prática, pertinente ao planejamento experimental, e sua caracterização de forma otimizada permite a obtenção de maior precisão e melhor qualidade nos resultados. Diante disso, objetivou-se determinar o tamanho de parcelas em experimentos de maracujazeiro em dois ensaios de uniformidade com a espécie Passiflora setacea e Passiflora alata. O experimento foi constituído de um substrato para plantio com três partes de solo e uma de esterco de curral curtido, o solo foi adubado com $3 \mathrm{~kg}$ de superfosfato simples e $0,5 \mathrm{~kg}$ de $\mathrm{KCl}$ por $1 \mathrm{~m}^{3}$. Cada espécie de passiflora foi considerada um ensaio de uniformidade com 40 unidades básicas (UB). As avaliações dos experimentos foram realizadas aos 60 dias após o transplante, observando-se altura da planta, diâmetro do caule, número de folhas, número de gemas e clorofila. Foram simulados diversos tamanhos de parcelas, em que cada planta foi considerada primeiramente como uma unidade básica até 40 plantas por unidade básica. Para a estimação do tamanho ótimo de parcelas empregou-se o método da máxima curvatura modificado. Os tamanhos de parcelas variaram com a espécie, encontrando-se valores de três a sete UB para Passiflora setacea e quatro a cinco UB para Passiflora alata.

Termos para indexação: Planejamento experimental, Precisão Experimental, Passiflora setacea, Passiflora alata.

${ }^{1} \mathrm{PhD}$ Professor, Mathematics Department, School of Engineering, Paulista State University ‘Júlio de Mesquita Filho', Ilha Solteira-SP, Brazil. E-mail: glaucia.a.faria@unesp.br (ORCID 0000-0003-2474-4840)

${ }^{2}$ MSc, University of São Paulo, Luiz de Queiroz College of Agriculture, Piracicaba-SP, Brazil. E-mail: biagarcialopes@gmail.com ${ }^{(O R C I D}$ :00000003-2605-6443)

${ }^{3}$ PhD Professor, Paraiba State University, Campina Grande-PB, Brazil. E-mail: patricia_uepb@yahoo.com.br(ORCID 0000-0003-0690-1144)

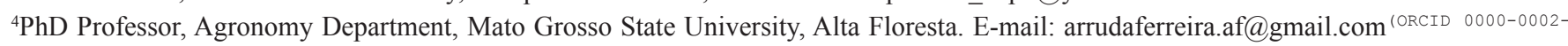
5879-8794)

${ }^{5} \mathrm{PhD}$ Professor, Department of Plant Protection, Rural Engineering and Soils, Paulista State University ‘Júlio de Mesquita Filho’, Ilha SolteiraSP, Brazil. E-mail: katia.maltoni@unesp.br (ORCID 0000-0001-6619-4504)

${ }^{6}$ MSc, Mathematics Department, School of Engineering, Paulista State University ‘Júlio de Mesquita Filho', Ilha Solteira-SP, Brazil. E-mail: mrpigari@gmail.com (ORCID 0000-0003-4015-3944) 


\section{Introduction}

Brazil is outstanding in the fruit growing sector, producing an average of 40 million tons of fruit in 2014 (FAO, 2017), making available an area of approximately 78 million hectares (IBGE, 2019). The production of passion fruit was $703,489 \mathrm{t}$, having a harvested area of 49,880 ha giving to the country the title of largest world's producer of this fruit. The northeast region is the largest producer in the country, accounting for about $62 \%$ of the national production, and Bahia state is the largest producer (IBGE, 2019).

In Brazil only two species have commercial interest: Passiflora edulis used for juice and Passiflora alata known as "sweet passion fruit". However, there are several species that may be promising for commercial production and/or studies aimed at increasing production and/or genetic improvement of the crop. Among the edible species, besides those mentioned, there are $P$. caerulea, P. setacea, P. nitida, P. macrocarpa, P. maliformis, and P. cincinnata. Of the species cultivated by ornamental aspect are $P$. coccinea, $P$. suberosa, and $P$. misera, and, for medicinal purposes are $P$. incarnata, $P$. alata, and $P$. edulis (JUNGHANS; JESUS, 2017).

Due to its economic importance and the need to carry out studies that promote the development of methodologies to be applied to increase production, conservation of germplasm, genetic improvement of these species, it is necessary to perform several experiments in different experimental conditions, using different species of Passiflora. Thus, studies aiming the choice of experimental design, size of plots, number of replicates make great allies of the researchers, since the definition of the experimental plot size is one of the most important factors in agricultural experimentation and varies depending on the experiment, since it depends of a series of factors, among them the place where the experiment is carried out (CARGNELUTTI FILHO et al., 2018).

It is known that one of the ways to reduce the experimental error is to increase the number of repetitions, in theory, the higher the number of repetitions, the greater the precision, since the increase in the number of degrees of freedom of the residue ensures higher estimates effects of treatments (BANZATTO; KRONKA, 2013). However, costs, time off, experimental area and available manpower can make experiments with fruit expensive, which would hamper the implementation and approval of projects in development agencies.

The calculation of the optimal size of plots for each type of experimentation may strengthen the fruit sector of the country. Among the methods most used for plot size calculation are the maximum curvature method (SMITH, 1938) and the modified maximum curvature method (LESSMAN; ATKINS, 1963). Both assume the same methodology and the second presents more robust estimates since the optimal point is found on the basis of statistics and not just by the visual. Althoug in most of the calculations using the two methods the values found and observed are very close.

In the fruticulture has been to calculate optimal plot size on papaya (CELANTI et al., 216ab), greenhouse papaya (LIMA et al., 2007), banana (DONATO et al., 2008) and passiflora in vitro (PEIXOTO et. al., 2011). The objective of this work was to calculate the optimal size of plots for greenhouse experiments with passion fruit cultivation using the modified maximum curvature method.

\section{Material and methods}

Two uniformity tests were carried out in the greenhouse of the UNESP - School of Engeneering, Department of Plant Technology, Food Technology and Socio-Economy (Ilha Solteira - SP). For each test, one of the species $P$. setacea $\mathrm{cv}$. BRS Pérola do Cerrado and $P$. alata cv. BRS Mel do Cerrado from Embrapa Cerrados, was used.

The substrate for planting consisted of three parts of soil and one of manure field (bovine), the soil was fertilized with $3 \mathrm{~kg}$ of simple superphosphate and 0.5 $\mathrm{kg}$ of $\mathrm{KCl}$ per $1 \mathrm{~m}^{3} \mathrm{~m}^{-2}$. A total of 100 seeds per species were used to germinate at $1 \mathrm{~cm}$ depth in styrofoam trays with 200 cells of $15.8 \mathrm{ml}$ of substrate per cell. After the germination, the plants were transplanted into trays with 2.51 of substrate. About 60 days after transplantation, the following variables were measured: Plant height, stem diameter, number of leaves, number of buds and chlorophyll by spectrophotometric method.

For the simulated plots of different forms, but with the same size, the arithmetic mean of the coefficients of variation, from different plot forms, was considered, and each passiflora species was considered as a blank. Thus, using the 40 basic units (BU), conveniently arranged in rows and columns in the grids, in each of the tests 25 different plot sizes were simulated, consisting of X1 basic units in the line and $\mathrm{X} 2$ basic units in the column.

The maximum curvature method modified by Lessman and Atkins (1963) was used to calculate plot size. This method incorporates Smith's (1938) soil heterogeneity coefficient, by establishing a relationship between coefficient of variation (CV) and plot size, represented by a regression equation of the potential type $y=a / x^{b}$, in which y represents the coefficient of variation, and $\mathrm{x}$ corresponding to the plot size in basic units (MEIER; LESSMAN, 1971) and lies in determining algebraically the point at which the curvature is maximum. 
The general equation $y=a / x^{b}$ defines the relationship between the variance of the response variable to be studied per unit area and the plot size in basic units $V_{x}=\frac{V_{1}}{x^{b}} \quad$ (LESSMAN; ATKINS, 1963) and also the relation between the coefficient of variation and the size of the plot when the appropriate constants $a$ and $b$ are known. The coefficients of variation are estimated in the blank tests using the expression $C V_{x}=\frac{\sqrt{S_{x}^{2}}}{\bar{x}} \times 100$, being $V_{x}=S_{x}^{2}$ the variance and $\bar{x}$ the average of the production of the plots of $\mathrm{x}$ basic units (LESSMAN and ATKINS, 1963), and justifies the use of the general equation for to relate the coefficient of variation and the size of the plot, that is, $C V_{x}=\frac{a}{b}$.

The parameters $a$ and $b$ can be estimated by the least squares method weighted by the respective deorees of freedom numbers. Thus, for the function $C V_{x}=\frac{a}{b^{x}}$, the point of maximum curvature can be estimated by the expression suggested by Meier and Lessmam (1971):

$$
X_{0}=\exp \left\{[1 /(2 b+2)] \log \left[(a b)^{2}(2 b+1) /(b+2)\right]\right\}
$$

where $a$ is the regression coefficient (intercept); and $b$, regression coefficient (slope). The analysis related to the plot size calculation was performed using the $\mathrm{R}$ program (R Development core team, 2018).

\section{Results and discussion}

The estimates of the parameters regression equations between the coefficient of variation and their corresponding plot size in basic units, with the respective coefficients of determination $\left(R^{2}\right)$, as well as the estimation of the adequate size of the plot $\left(X_{c}\right)$ for the two passiflora species and their respective variables are presented in Table 1. The coefficient of variation ranged from 7.59 to $16.6 \%$ for $P$. setacea species and 6.51 to $15.1 \%$ for $P$. alata species. Verify that for the species $P$. setacea the plot sizes found ranged from 2.81 (Number of buds) to 6.26 (Height), with coefficients of determination $\left(R^{2}\right)$ of 0.83 and $0.91 \%$, respectively. For $P$. alata the values found were 3.92 (Diameter) to 4.97 (Number of leaves), with determination coefficients of 0.83 and $0.94 \%$, respectively.

Table 1. Estimates of the parameters of the relation $C V_{(\mathrm{x})}=\mathrm{a} / \mathrm{x}^{\mathrm{b}}$, by the method of maximum modified curvature, a coefficient of variation $(C V \%)$, abscissa value in which the point of maximum curvature occurs $\left(X_{c}\right)$, determination coefficients $\left(R^{2}\right)$ for the analyzed variables of the species $P$. setacea and $P$. alata.

\begin{tabular}{ccccccc}
\hline \multirow{2}{*}{ Species } & Variables & \multicolumn{2}{c}{ Parameters } & $\begin{array}{c}\text { Coefficient of } \\
\text { variation }\end{array}$ & Plot Size & $\begin{array}{c}\text { Coefficient of } \\
\text { determination }\end{array}$ \\
\cline { 3 - 7 } & & $\hat{\mathrm{a}}$ & $\hat{\mathrm{b}}$ & $C V$ & $X_{c}$ & $R^{2}$ \\
\hline \multirow{4}{*}{ P. setacea } & Height & 36.0 & 0.45 & 15.6 & 6.26 & 0.91 \\
& Diameter & 26.9 & 0.32 & 16.6 & 4.48 & 0.83 \\
& $\mathrm{~N}^{\circ}$ of leaves & 17.5 & 0.59 & 7.59 & 4.11 & 0.94 \\
& $\mathrm{~N}^{\circ}$ of buds & 21.2 & 0.42 & 17.1 & 2.81 & 0.83 \\
& Chlorophyll & 25.6 & 0.39 & 13.8 & 4.74 & 0.90 \\
\hline \multirow{5}{*}{ P. alata } & Height & 27.8 & 0.22 & 20.8 & 3.71 & 0.78 \\
& Diameter & 23.1 & 0.309 & 15.1 & 3.92 & 0.87 \\
& $\mathrm{~N}^{\circ}$ of leaves & 25.0 & 0.488 & 11.4 & 4.97 & 0.96 \\
& $\mathrm{~N}^{\circ}$ of buds & 18.1 & 0.636 & 7.21 & 4.26 & 0.94 \\
& Chlorophyll & 17.6 & 0.727 & 6.51 & 4.24 & 0.97 \\
\hline
\end{tabular}

From the estimates of the coefficient $(a)$, the regression intercept, which estimates the maximum $\mathrm{CV}$, it is noted that there was little variation of values (Table 1) suggesting uniformity between the variables in the two species. With respect to the regression coefficient (b) that can be seen as a measure of variability of the study material, so that values close to zero indicate low variability and values close to one indicate high variability, it is observed the occurrence of higher variability for the chlorophyll variable in the P. alata species (Table 1).
It is observed that $P$. alata species had lower variability than $P$. setacea between the estimated plot sizes, which ranged from 3.71 to 4.97 and 2.81 to $6.26 \mathrm{UBs}$, respectively, with a coefficient of variation between 7.59 to 17.1 and 6.51 to 20.8. respectively. With determination coefficients above $70 \%$ in all cases with values ranging from 0.78 to 0.97 in P. alata and 0.83 to 0.94 P. setacea (Table 1). 
Figures 1 and 2 shows the graphs of the $\mathrm{CV}$ ratio and plot size obtained by the modified maximum curvature method for the species Passiflora setacea and Passiflora alata respectively, from which it is possible to determine that the inflection point of the curve, which is the point where the ideal plot size is defined. These figures show the coefficients of variation (CV) of the fourteen different plot sizes in UBs $(\mathrm{X})$ considering all the variables in the two species studied. It was found in all cases that the highest $C V$ value was obtained in the smallest plot size, a basic unit (UB). Continuous CV reduction for most of the analyzed variables occurred non-linearly up to five UB, which shows that the accuracy gain by adding more units is not significant when the appropriate portion size is reached.
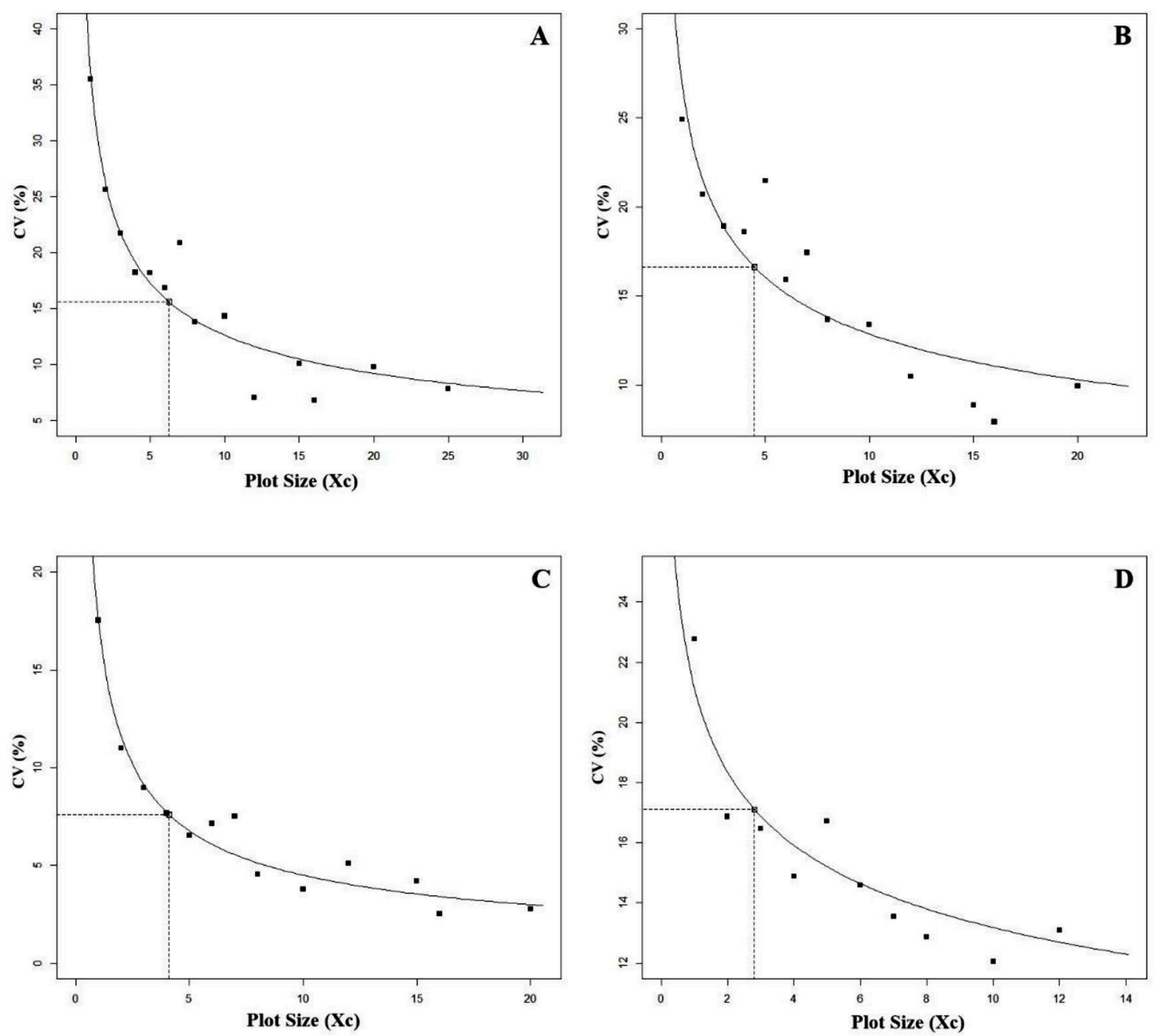

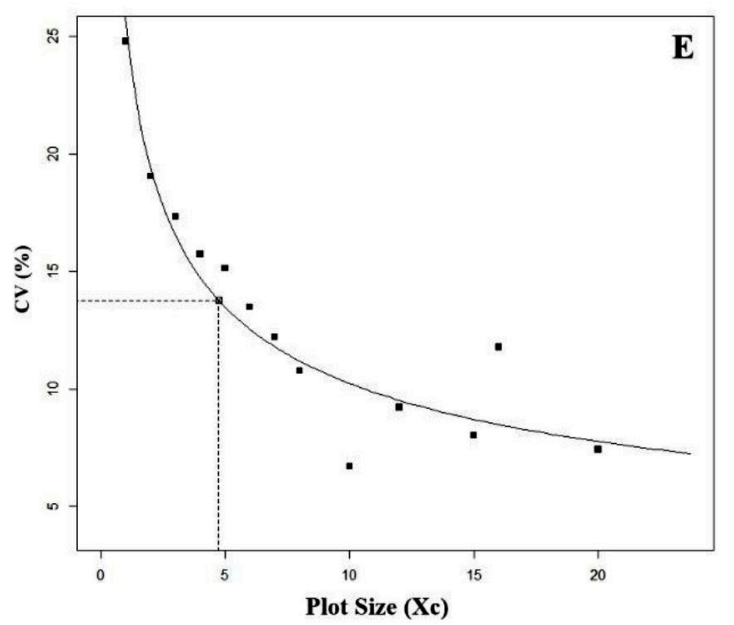

Figure 1. Relationship between the coefficient of variation CV (\%) and plot size $\left(X_{c}\right)$ for the variables height (A), diameter (B), number of leaves (C), buds (D) and chlorophyll (E) of the species P. setacea. 

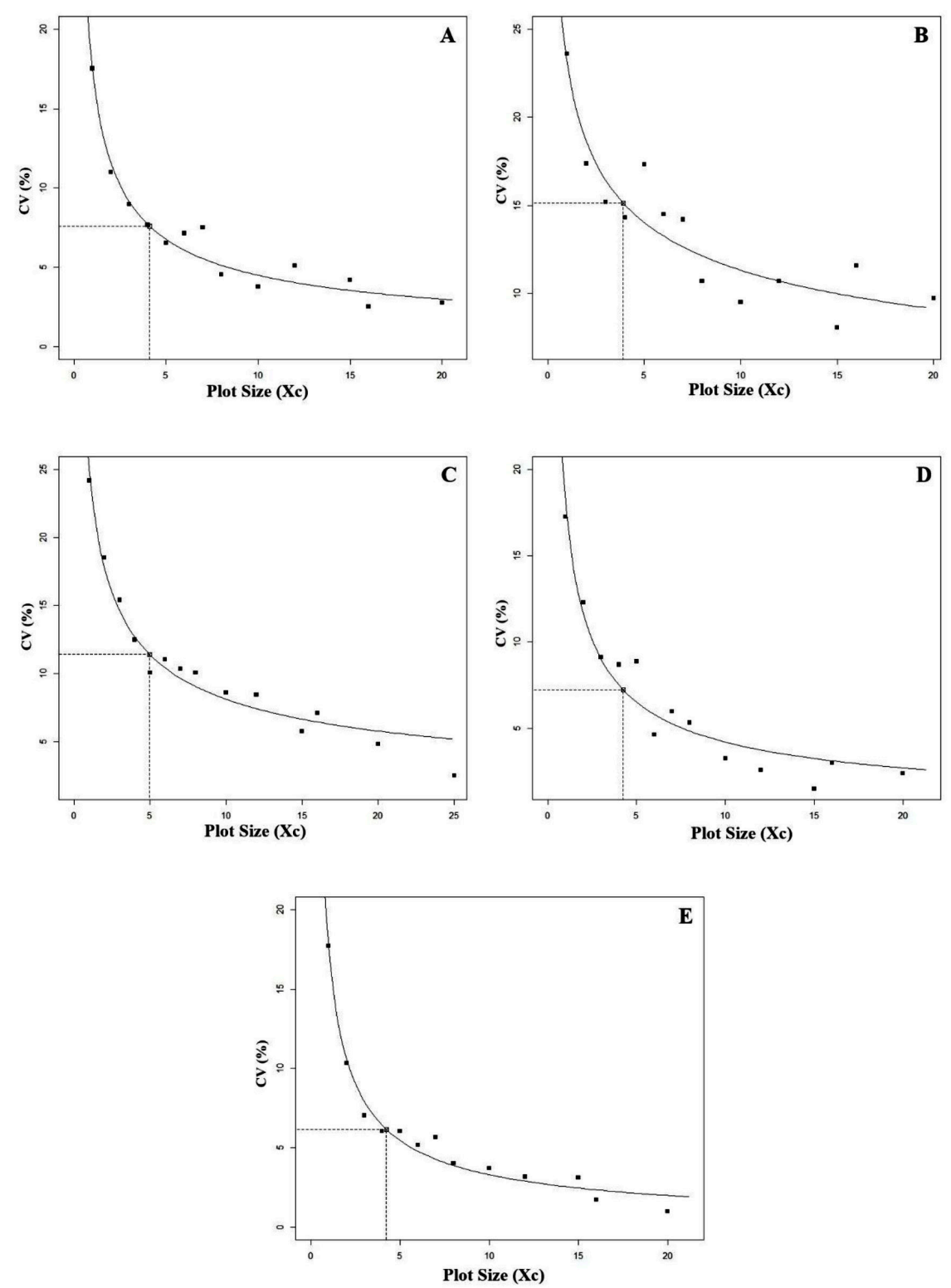

Figure 2. Relationship between the coefficient of variation CV (\%) and plot size $\left(X_{c}\right)$ for the variables height (A), diameter (B), number of leaves (C), buds (D) and chlorophyll (E) of $P$. alata species.

Because the plot size is estimated algebraically, the values obtained are not necessarily integers, which leads to the possibility of rounding upwards, since this method estimates small values of plot sizes, with the possibility of decreasing the coefficient of variation with the increase of plot size in the region superior to the point of maximum curvature, as described by Henriques Neto et al. (2004) and this behavior was also verified by Oliveira et al. (2011) and Donato et al. (2008).

The modified maximum curvature method is the most suitable for calculating the optimal plot size, not underestimating or overestimating the plot size as may occur in the linear plate and quadratic plate methods (SOUSA et al., 2015; DONATO et al., 2008; LOPES et al. 2005). In studies with comparisons between the maximum curve method and the linear regression with plate, Sousa
(2015), Brito et al. (2012), Oliveira et al. (2011) and Paranaíba et al. (2009), found that the plot size obtained by the maximum curvature method was smaller than that obtained by the linear regression method.

In fruit trees were found plots with $12 \mathrm{BU}$ in grapevine, $10 \mathrm{BU}$ in strawberry soil cultivated and $6 \mathrm{BU}$ in strawberry hydroponic cultivation (COCCO et al., 2010). Celanti et al. (2016ab) used the maximum curvature method found $5 \mathrm{BU}$ in papaya and Peixoto et al. (2011) used the linear regression model with plateau, with in vitro passion fruit found $6 \mathrm{BU}$. 


\section{Conclusion}

In experiments with $P$. setacea and $P$. alata species, there are little variability in relation to the plot size found according to the modified maximum curvature method. It is suggested to use plots formed by five basic units in experiments with these species since it was the number of units that satisfied all the variables tested.

\section{References}

BANZATTO, D.A.; KRONKA, S.N. Experimentação agrícola. 4.ed. Jaboticabal: Funep, 2013. 237 p.

BRITO, M.C.M.; FARIA, G.A.; MORAIS, A.R.; SOUZA, E.M.; DANTAS, J.L.L. Estimação do tamanho ótimo de parcela via regressão antitônica. Revista Brasileira de Biometria, São Paulo, v.30, n.3, p.353-366, 2012.

CARGNELUTTI FILHO, A. Plot size related to numbers of treatments and replications, and experimental precision in dwarf pigeon pea. Bragantia, Campinas, v.77, n.2, p.212-220, 2018.

CELANTI, H.F.; SCHMILDT, E.R.; SCHMILDT, O.; ALEXANDRE, R.S.; CATTANEO, L.F. Optimal plot size in the evaluation of papaya scions: proposal and comparison of methods. Revista Ceres, Viçosa, MG, v.63, n.4, p.469-476, 2016 b.

CELANTI, H.F.; SCHMILDT, O.; ALEXANDRE, R.S.; CATTANEO, L.F.; SCHMILDT, E.R. Plot size in the evaluation of papaya seedlings 'Baixinho de Santa Amália' in tubes. Revista Brasileira de Fruticultura, Jaboticabal, v. 38, n. 3, e-553, 2016a.

COCCO, C.; BOLIGON, A.A.; ANDRIOLO, J.L.; OLIVEIRA, C.S.; LORENTZ, L.H. Tamanho e forma de parcela em experimentos com morangueiro cultivado em solo ou em hidroponia. Pesquisa Agropecuária Brasileira, Brasília, DF, v.44, n.7, p.681-686, 2010.

DONATO, S.L.R.; SIQUEIRA, D.L.; SILVA, S.O.E; CECON, P.R.; SILVA, J.A.; SALOMÃO, L.C.C. Estimativas de tamanho de parcelas para avaliação de descritores fenotípicos em bananeira. Pesquisa Agropecuária Brasileira, Brasília, DF, v.43, n.8, p.957969, 2008.

FAO - Organização das Nações Unidas para a Agricultura e Alimentação. FAOSTAT. Divisão de estatística. 2017. Disponível em: http://faostat3.fao.org/download/Q/QC/E. Acesso em: Acesso em: 10 de agosto de 2019.
HENRIQUES NETO, D.; SEDIYAMA, T.; SOUZA, M.A.; CECON, P.R.; YAMANAKA, C.H.; SEDIYAMA, M.A.N.; VIANA, A.E.S. Tamanho de parcelas em experimentos com trigo irrigado sob plantio direto e convencional. Pesquisa Agropecuária Brasileira, , Brasília, DF, v.39, n.6, p.517-524, 2004.

IBGE - Instituto Brasileiro de Geografia Estatística. Produção Agrícola Municipal. Área plantada ou destinada à colheita, área colhida, quantidade produzida, rendimento médio e valor da produção das lavouras temporárias e permanentes. Rio de Janeiro, 2019. Disponível em: https://sidra.ibge.gov. br/tabela/5457. Acesso em: 10 de agosto de 2019.

JUNGHANS, T.G.; JESUS, O.N. Maracujá: do cultivo a comercialização. Brasília: Embrapa, 2017. 341 p.

LESSMAN, K.J.; ATKINS, R.E. Optimum plot size and relative efficiency of lattice designs for grain sorghum yield test. Crop Science, Madison, v.3, n.6, p.477-481, 1963.

LIMA, J.F.; PEIXOTO, C.P.; LEDO, C.A.S.; FARIA, G.A. Tamanho ótimo de parcela para experimentos com plantas de mamoeiro em casa de vegetação. Revista Ciência e Agrotecnologia, Lavras, v.31, n.5, p.1411-1415, 2007.

LOPES, S.J.; STORCK, L.; LÚCIO, A.D.C.; LORENTZ, L.H.; LOVATO, C.; DIAS, V.O. Tamanho de parcela para produtividade de grãos de sorgo granífero em diferentes densidades de plantas. Pesquisa Agropecuária Brasileira, Brasília, DF, v.40, n.6, p.525-530, 2005.

MEIER, V.D.; LESSMAN, K.J. Estimation of optimum field plot shape and size for testing yield in Crambe abyssinica Hochst, Crop Science, Madison, v, 11, p, 648650, 1971.

OLIVEIRA, G.M.V.; OLIVEIRA, G.M.V.; MELLO, J.M.; LIMA, R.R.; SCOLFORO, J.R.S.; OLIVEIRA, A.D. Tamanho e forma de parcelas experimentais para Eremanthus erythropappus. Cerne, Lavras, v.17, n.3, p.327-338, 2011.

PARANAÍBA, P.F.; FERREIRA, D.F.; MORAIS, A.R. Tamanho ótimo de parcelas experimentais: proposição de métodos de estimação. Revista Brasileira de Biometria, Lavras, v.27, n.2, p.255-268, 2009.

PEIXOTO, A.P.B.; FARIA, G.A.; MORAIS, A.R. Modelos de regressão com platô na estimativa do tamanho de parcelas em experimento de conservação in vitro de maracujazeiro. Ciência Rural, Santa Maria, v.11, n.41, p.1907-1913, 2011. 
R CORE TEAM. R: A language and environment for statistical computing. Viena: R Foundation for Statistical Computing. 2018. Disponível em: http://www.R-project. org/.

SMITH, H.F. An empirical law describing heterogeneity in the yields of agricultural crops. The Journal of Agricultural Science, Cambridge, v.28, n.1, p.1-23, 1938
SOUSA, R.P.; SILVA, P.S.; ASSIS, J.P.; SILVA, J.; OLIVEIRA, V.R.; OLIVEIRA, A.M. de P. Tamanho ótimo de parcela para avaliação do rendimento de grãos do girassol. Revista Brasileira de Engenharia Agricola e Ambiental, Campina Grande, v.19, n.1, p.21-26, 2015. 